\title{
IDENTIFIKASI POTENSI KESESUAIAN PERAIRAN UNTUK BUDIDAYA RUMPUT LAUT DI TELUK MULUT SERIBU, ROTE NDAO, NUSA TENGGARA TIMUR
}

\author{
Ariani Andayani ${ }^{\#}$ dan Amin Pamungkas \\ Pusat Riset Perikanan \\ Gedung BRSDMKP II, Jl. Pasir Putih II, Ancol Tmur, Jakarta Utara 14430 \\ (Naskah diterima: 14 Juni 2017; Revisi final: 3 Mei 2018; Disetujui publikasi: 3 Mei 2018)
}

\begin{abstract}
ABSTRAK
Rumput laut merupakan salah satu komoditas unggulan sektor perikanan. Salah satu sentra budidaya rumput laut yang akan dikembangkan adalah Kabupaten Rote Ndao, yang memiliki ketersediaan perairan potensial untuk pengembangan budidaya rumput laut. Kajian kesesuaian perairan untuk budidaya rumput laut perlu dilakukan untuk keberlanjutan budidaya. Penelitian ini bertujuan untuk mengkaji karakteristik dan kesesuain perairan untuk pengembangan budidaya rumput laut di Teluk Mulut Seribu, Rote Ndao. Pengambilan data kualitas perairan dilakukan dengan pengukuran langsung dan mengambil sampel untuk dianalisis di laboratorium. Distribusi spasial kualitas perairan di area kajian diinterpolasi menggunakan metode IDW dengan perangkat lunak ArcGIS. Ada 4 parameter yang diperhitungkan dalam analisis spasial, yaitu: kedalaman, kecepatan arus, kecerahan dan alur layar, yang ditumpangsusun tanpa pembobotan untuk mendapatkan peta kesesuaian. Sementara itu beberapa parameter lainnya tidak masuk dalam analisis spasial karena kisaran nilainya sudah sesuai untuk budidaya rumput laut. Hasil penelitian menunjukan bahwa kesesuaian lahan untuk budidaya rumput laut di perairan Mulut Seribu mencapai 56\%atau 497,68 hektar dari 879,18 hektar area kajian. Area yang sesuai untuk budidaya rumput laut tersebut memiliki potensi panen hingga 50 ton per siklus.
\end{abstract}

\section{KATA KUNCl: $\quad$ budidaya rumput laut; analisis spasial; Rote Ndao}

ABSTRACT: Identification of potential suitability area for seaweed farming in Mulut Seribu Bay, Rote Ndao,
East Nusa Tenggara. By: Ariani Andayani and Amin Pamungkas

Seaweed is one of the leading commodities in fisheries sector. In Rote Ndao regency, plans to develop seaweed aquaculture centers have been advised considering the regency's potential coastline areas for seaweed farms. However, a site suitability study is needed to determine if the area is suitable for seaweed aquaculture to ensure its long term sustainability. This study was aimed to examine the characteristics and suitability of Teluk Mulut Seribu waters in Rote $\mathrm{Ndao}$ for seaweed cultivation. Data collection on water quality parameters was done via in-situ measurement and samples were collected to be analysed ex-situ in the laboratory. The full extent of spatial distributions of water quality parameters was determined using IDW interpolation tool available in ArCGIS. Thefour parameters used in the spatial analysis, namely: depth, current velocity, brightness, and sea transportation line were overlaid using non-weighted arithmetic mean operation to create a final composite of suitability map. The other measured parameters were not included in the spatial analysis because the value ranges were considered suitable for seaweed cultivation. The results showed that 56\%or 497.68 ha from 879.18 ha of seascape in Teluk Mulut Seribu are suitable for seaweed farming. This study recommends that these suitable areas can be used for seaweed aquaculturewith a predicted harvest potential up to 50 ton per culture cycle.

KEYWORDS: $\quad$ seaweed farming; spatial analysis; Rote Ndao

\section{PENDAHULUAN}

Rumput laut menjadi salah satu komoditas perikanan yang menjadi perhatian pemerintah saat ini.

\footnotetext{
\# Korespondensi: Pusat Riset Perikanan. Gedung BRSDM KP II, Jl. Pasir Putih II, Ancol Tmur, Jakarta Utara 14430, Indonesia. Tel.: + 622164700928

E-mail: arianiandayani@gmail.com
}

Hal ini diperkuat dalam Lampiran Peraturan Presiden RI Nomor 3 Tahun 2017 tentang rencana aksi percepatan pembanguan industri perikanan nasional, salah satunya adalah percepatan industri rumput laut nasional. Peningkatan produksi dan kontinuitas bahan baku rumput laut harus dicapai untuk mewujudkan hal tersebut. Salah satu lokasi yang menjadi perhatian 
Kementerian Kelautan dan Perikanan untuk mendukung bahan baku rumput laut adalah di Kabupaten Rote Ndao.

Kabupaten Rote Ndao merupakan kawasan terluar Indonesia bagian selatan yang berbatasan langsung dengan Australia. Lokasi ini termasuk yang terpilih untuk diprioritaskan pembangunannya sebagai sentra kelautan dan perikanan terpadu yang ditetapkan oleh Kementerian Kelautan dan Perikanan (KKP, 2016). Sektor potensial yang akan dikembangkan adalah budidaya rumput laut.

Produksi rumput laut nasional tahun 2015 mencapai 10.112.107 ton, Provinsi Nusa Tenggara Timur (NTT) menyumbangkan produksi sebesar 2.283.331 ton atau 22,5\%dari produksi rumput laut nasional. Kabupaten Rote Ndao menyumbangkan produksi sekitar $6,86 \%$ atau 156.816 ton dari produksi Provinsi NTT (DJPB, 2015). Saat ini baru sekitar 8,69\%lahan yang digarap dari potensi areal budidaya rumput laut yang tersedia (Pemerintah Kabupaten Rote Ndao, 2009) sehingga masih memungkinkan untuk peningkatan produksi rumput laut di Rote Ndao.

Perencanaan dalam budidaya rumput laut perlu dilaksanakan, untuk mendukung keberlanjutan usaha budidaya. Pengetahuan tentang lingkungan perairan dan data berbagai faktor yang cocok bagi kegiatan budidaya rumput laut masih sangat diperlukan; oleh karena itu, pengembangan budidaya rumput laut perlu adanya kajian kelayakan lokasi untuk mengantisipasi kegagalan budidaya (Mustafa et al., 2017).

Kelayakan lokasi merupakan hasil kesesuaian di antara persyaratan hidup dan berkembangnya rumput laut terhadap lingkungan fisik perairan. Lingkungan fisik yang dimaksud meliputi kondisi arus dan kualitas perairan, serta topografi dasar laut (Mudeng et al., 2015). Hasnawi et al. (2013) menggunakan beberapa parameter untuk menentukan kesesuaian lahan rumput laut di Kabupaten Parigi Moutong. Parameter yang digunakan adalah data kedalaman, kecerahan, salinitas, suhu, dan nitrat, jarak ke pemukiman dan jarak ke sungai.

Masyarakat Pulau Rote telah melaksanakan budidaya rumput laut. Sistem budidaya rumput laut yang dilakukan yaitu dengan menggunakan sistem long line. Rata-rata luasan areal budidaya $50 \mathrm{~m} \times 50 \mathrm{~m}$, sampai dengan $100 \mathrm{~m} \times 200 \mathrm{~m}$, dengan 2-4 siklus produksi dalam setahun. Jenis rumput laut yang dibudidayakan yaitu Kappaphycus striatum yang biasa masyarakat setempat menyebutnya sacol (sakol). Hasil penelitian ini diharapkan dapat menjadi rujukan bagi pembudidaya rumput laut di Pulau Rote dalam memilih lokasi budidaya rumput laut.
Tujuan dari penelitian ini adalah untuk mengkaji karakteristik dan kesesuaian perairan untuk pengembangan budidaya rumput laut di Teluk Mulut Seribu, Rote Ndao.

\section{BAHAN DAN METODE}

\section{Lokasi Penelitian}

Penelitian ini dilakukan di Teluk Mulut Seribu, Kecamatan Rote Timur, Kabupaten Rote Ndao, Provinsi Nusa Tenggara Timur (Gambar 1). Penentuan lokasi penelitian berdasarkan diskusi dengan Dinas Kelautan dan Perikanan dan BAPPEDA Kabupaten Rote Ndao.

\section{Pengumpulan Data}

Data yang digunakan dalam penelitian ini adalah data primer kualitas air dan batimetri yang diperoleh melalui survai lapangan, serta data sekunder berupa Peta Rupa Bumi Indonesia Kabupaten Rote Ndao skala 1:50.000 dalam bentuk digital dari Badan Informasi Geospatial tahun 2013. Pengambilan data lapangan dilakukan pada bulan Mei 2016. Kondisi perairannya masih tergolong baik, belum banyak masukan pencemaran dari darat akibat aktivitas manusia seperti industri dan pertanian. Data diambil hanya satu kali mewakili musim kemarau. Dalam Perda Kabupaten Rote Ndao No. 4 Tahun 2014 (Pemerintah Kabupaten Rote Ndao, 2014) menyebutkan bahwa musim kemarau di Rote Ndao berlangsung hingga delapan bulan (AprilNovember) dan musim hujan lebih pendek hanya empat bulan (Desember-Maret), dengan curah hujan yang relatif rendah 1.401,8-2.167,5 mm per tahun.

Penentuan titik pengambilan data kualitas perairan dirancang dengan mempertimbangkan jarak dari garis pantai dan menyebar secara proporsional. Jarak antara titik pengambilan sampel sekitar 300-500 meter. Pengambilan data kualitas perairan dilakukan dengan pengukuran langsung di lapangan dan dengan cara pengambilan sampel air untuk dianalisis di laboratorium Proling Institut Pertanian Bogor (IPB). Titik pengukuran sampel di lapangan sejumlah 39 titik dan untuk pengukuran laboratorium ada 15 titik. Metode pengambilan contoh uji air laut mengacu pada SNI 6964.8:2015 (BSN, 2015).

Parameter yang diukur langsung di lapangan meliputi: suhu, pH, salinitas, DO, batimetri, kecerahan perairan, arus, dan sedimen dasar. Pengukuran suhu, pH, salinitas, dan DO menggunakan YSI multiparameter instrument.

Kedalaman (batimetri) diukur menggunakan Garmin Mapsounder 585, beroperasi pada frekuensi $200 \mathrm{kHz}$ 

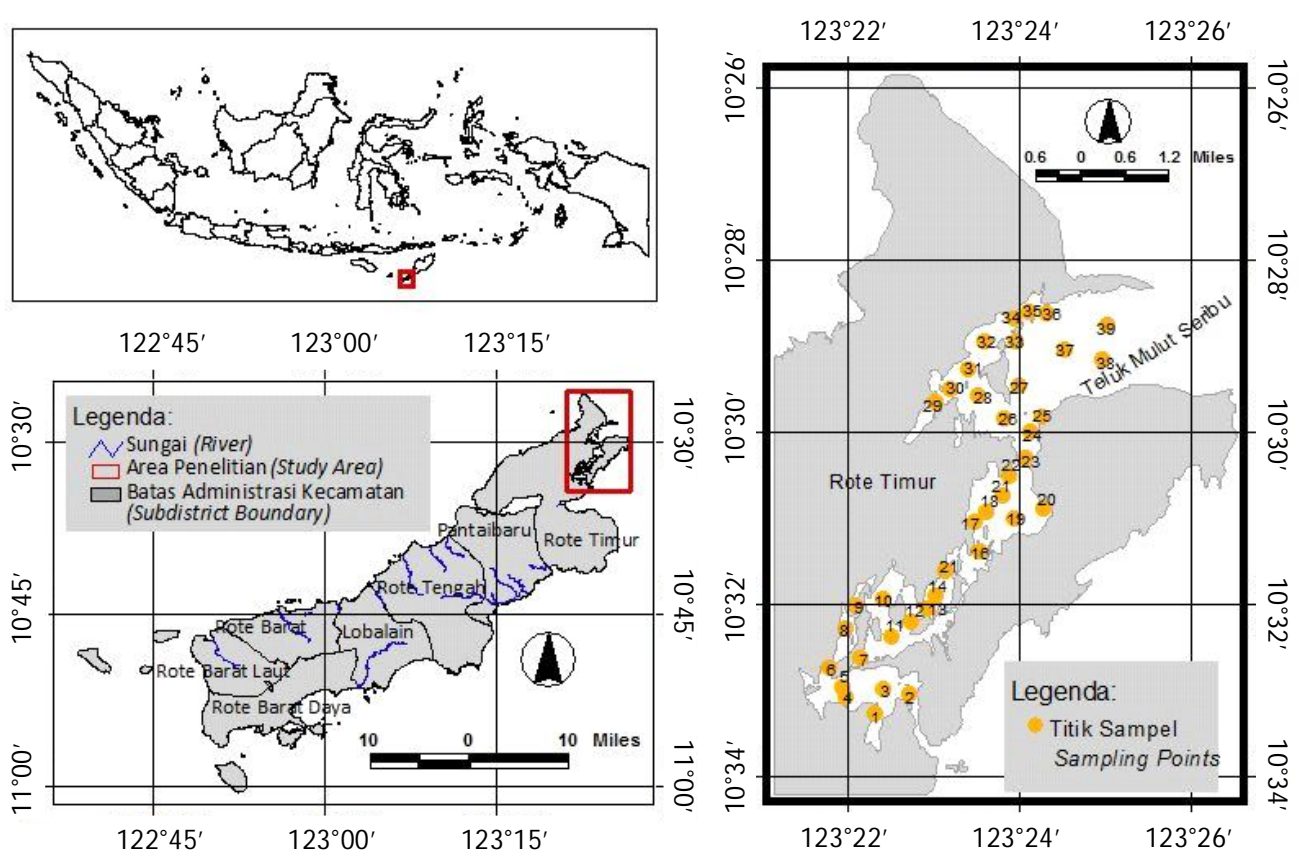

Gambar 1. Lokasi penelitian dan sebaran titik pengambilan sampel di Teluk Mulut Seribu.

Figure 1. Study area and distribution of sampling points in Mulut Seribu Bay.

yang dipasang pada sisi kanan lambung kapal dengan kecepatan kapal pada saat survai \pm 4 knot. Lajur pemeruman melintang mengikuti garis pantai teluk.

Pengukuran kecepatan arus dilakukan pada setiap titik sampling menggunakan current meter yang dicelupkan pada kedalaman 1-2 m selama \pm 5 menit. Kecerahan perairan diukur pada setiap titik sampling menggunakan sacchi disk dengan cara menggunakan tali yang telah diberi skala dalam satuan meter, hingga tidak terlihat oleh pandangan mata kemudian menarik kembali sacchi disk tersebut hingga kembali terlihat. Rerata hasil pembacaan skala pada saat menurunkan dan menaikkan kembali sacchi tersebut kemudian dicatat sebagai nilai kecerahan. Pengambilan sampel sedimen menggunakan Ekman Grab Sample, sedimen hasil sampling kemudian disimpan dalam wadah plastik dan dikirim ke laboratorium Proling IPB.

Pengambilan contoh air dilakukan untuk mengidentifikasi beberapa parameter kualitas perairan berupa total suspended solid (TSS), nitrat, nitrit, fosfat, dan amonia. Sampling TSS dilakukan mengambil sampel air laut dengan volume satu liter menggunakan Van Dorn water sampler kemudian disaring menggunakan vacuum pump dengan kertas saring berukuran pori $0,45 \mathrm{im}$. Kertas saring dilipat, kemudian disimpan dalam plastik sampel dan penyimpanan pada suhu dingin. Nitrat, nitrit, fosfat, dan amonia, di-sampling menggunakan Van Dorn water sampler pada kedalaman
$3 \mathrm{~m}$, air yang di-sampling kemudian disimpan pada wadah botol PE berukuran satu liter dan diberi pengawet $\left(\mathrm{H}_{2} \mathrm{SO}_{4}\right)$.

Dalam penelitian ini tidak melaksanakan pengukuran pasang surut, namun mengambil dari hasil pengukuran sebelumnya (Pemerintah Kabupaten Rote Ndao, 2015). Berdasarkan dokumen tersebut diperoleh nilai mean sea level (MSL) sebesar $274 \mathrm{~cm}$, nilai MSL tersebut digunakan untuk mengoreksi nilai kedalaman yang diperoleh dari pemeruman.

\section{Analisis Data}

Data kualitas perairan masih berupa data atribut yang dipresentasikan dalam bentuk titik (point). Data tersebut kemudian diinterpolasi menggunakan perangkat lunak ArcGIS untuk dapat dianalisis secara spasial. Metode interpolasi yang digunakan dalam penelitian ini adalah inverse distance weighted (IDW). Pramono (2008) menyatakan bahwa metode IDW memberikan hasil interpolasi yang lebih akurat dari metode kriging, hal ini ditunjukkan dengan nilai interpolasi metode IDW mendekati nilai minimum dan maksimum dari sampel data TSS. Affan (2012) dan Radiarta et al. (2006) juga menyebutkan bahwa interpolasi data fisik wilayah pesisir lebih tepat menggunakan metodeIDW karena tidak menghasilkan nilai melebihi data yang disampel. 
Khusus untuk data kualitas perairan yang nilai minimum hingga nilai maksimumnya memiliki nilai yang sesuai dengan kriteria (sesuai dengan Tabel 1), maka tidak dilakukan interpolasi, hal ini dikarenakan seluruh nilainya akan masuk kategori kelas sesuai. Data kulitas perairan yang diinterpolasi adalah data kualitas perairan yang nilai minimumnya dan maksimumnya bervariasi (ada yang masuk dalam kategori sesuai dan tidak sesuai). Semua nilai yang tidak masuk dalam kriteria sesuai (Tabel 1) akan dikelompokan ke dalam kelas tidak sesuai.

Data hasil interpolasi masing-masing parameter hasilnya berupa data raster. Data Raster tersebut kemudian dikelaskan (reclassify) menjadi dua kelas, yaitu kelas sesuai dan tidak sesuai, kelas sesuai diberi nilai digital-1 dan kelas tidak sesuai diberi nilai digital-0. Kemudian beberapa parameter kualitas air yang telah dikelaskan tersebut di-overlay secara raster (raster math), hasilnya kemudian dikelaskan kembali menjadi dua kelas.
Alur pelayaran merupakan area yang harus dihindari untuk budidaya rumput laut. Alur pelayaran yang berupa data vektor garis dilakukan buffering sejauh $100 \mathrm{~m}$, kemudian digabungkan dengan data area laut (area penelitian) lalu dikonversi menjadi data raster agar dapat di-overlay secara raster dengan data hasil interpolasi. Area buffering dikelaskan sebagai area tidak sesuai sehingga diberi nilai 0 . Diagram alir pemrosesan data disajikan pada Gambar 2.

\section{HASIL DAN BAHASAN}

\section{Kondisi Umum Kualitas Perairan}

Hasil pengukuran secara langsung maupun analisis laboratorium mengenai kondisi fisik-kimia kawasan perairan pada Teluk Mulut Seribu disajikan pada Tabel 2. Dalam penelitian ini memperhitungkan 14 parameter guna menentukan lokasi yang sesuai untuk budidaya rumput laut. Hasil pengukuran tersebut kemudian dicocokkan dengan kriteria kesesuaian lahan

Tabel 1. Kriteria kesesuaian lahan untuk budidaya rumput laut

Table 1. Criteria of site suitability for seaweed aquaculture

\begin{tabular}{|c|c|c|}
\hline Parameter (Parameters ) & Sesuai & Sumber (Sources) \\
\hline $\begin{array}{l}\text { Keterlindungan } \\
\text { Sheltered }\end{array}$ & $\begin{array}{l}\text { Terlindung } \\
\text { Sheltered }\end{array}$ & BSN (2010) \\
\hline $\begin{array}{l}\text { Batimetri } \\
\text { Bathymetry (m) }\end{array}$ & $2-15$ & $\begin{array}{l}\text { BSN (2010); Hasnawi et al . (2013); } \\
\text { Pong-Masak et al . (2010) }\end{array}$ \\
\hline $\begin{array}{l}\text { Kecepatan arus } \\
\text { Current speed }\end{array}$ & $10-40 \mathrm{~cm} / \mathrm{dt}$ & Akbar (2014); BSN (2010); Ariyati et al. (2007) \\
\hline $\begin{array}{l}\text { Kecerahan perairan } \\
\text { Transparency }(\mathrm{m})\end{array}$ & $>3$ & $\begin{array}{c}\text { Akbar (2014); Hasnawi et al . (2013); } \\
\text { Pong-Masak et al . (2010) }\end{array}$ \\
\hline $\mathrm{pH}$ & $7-8.5$ & BSN (2010); Bakosurtanal (2005); KLH (2004) \\
\hline $\begin{array}{l}\text { Suhu } \\
\text { Temperature }\left({ }^{\circ} \mathrm{C}\right)\end{array}$ & $26-32$ & $\begin{array}{c}\text { Ariyati et al . (2007); BSN (2010); } \\
\text { Mudeng et al. (2015) }\end{array}$ \\
\hline $\begin{array}{l}\text { Salinitas } \\
\text { Salinity (ppt) }\end{array}$ & $28-24$ & $\begin{array}{l}\text { Ariyati et al . (2007); BSN (2010); } \\
\text { Bakosurtanal (2005); Juanich (1988) }\end{array}$ \\
\hline $\begin{array}{l}\text { Dasar perairan } \\
\text { Bottom seabed }\end{array}$ & $\begin{array}{l}\text { Pasir berbatu karang } \\
\text { Rocky sand }\end{array}$ & BSN (2010); Pong-Masak et al . (2010) \\
\hline $\begin{array}{l}\text { Oksigen terlarut } \\
\text { Dissolved oxygen (DO) }\end{array}$ & $>4 \mathrm{mg} / \mathrm{L}$ & Ariyati et al . (2007) \\
\hline Amonia (Ammonia) $\left(\mathrm{NH}_{3}\right)$ & $<0.3 \mathrm{mg} / \mathrm{L}$ & KLH (2004) \\
\hline Nitrat (Nitrate) $\left(\mathrm{NO}_{3}-\mathrm{N}\right)$ & $0.1-0.7 \mathrm{mg} / \mathrm{L}$ & Ariyati et al . (2007) \\
\hline Fosfat (Phosphate) & $\begin{array}{c}0.02-0.2 \mathrm{mg} / \mathrm{L} \\
<25 \mathrm{mg} / \mathrm{L}\end{array}$ & Ariyati et al . (2007) \\
\hline $\begin{array}{l}\text { Total padatan tersuspensi } \\
\text { Total suspended solid (TSS) }\end{array}$ & $\begin{array}{c}\text { (diinginkan/Expected) } \\
<80 \mathrm{mg} / \mathrm{L} \\
\text { (diperbolehkan/Allowed) }\end{array}$ & KLH (1988) \\
\hline $\begin{array}{l}\text { Alur pelayaran } \\
\text { Sea transportation line }\end{array}$ & $>100 \mathrm{~m}$ & $\begin{array}{l}\text { Keputusan ahli } \\
\text { Expert judgment }\end{array}$ \\
\hline
\end{tabular}

Keterangan (Note): Kriteria ini disusun dari berbagai sumber dengan sedikit modifikasi 


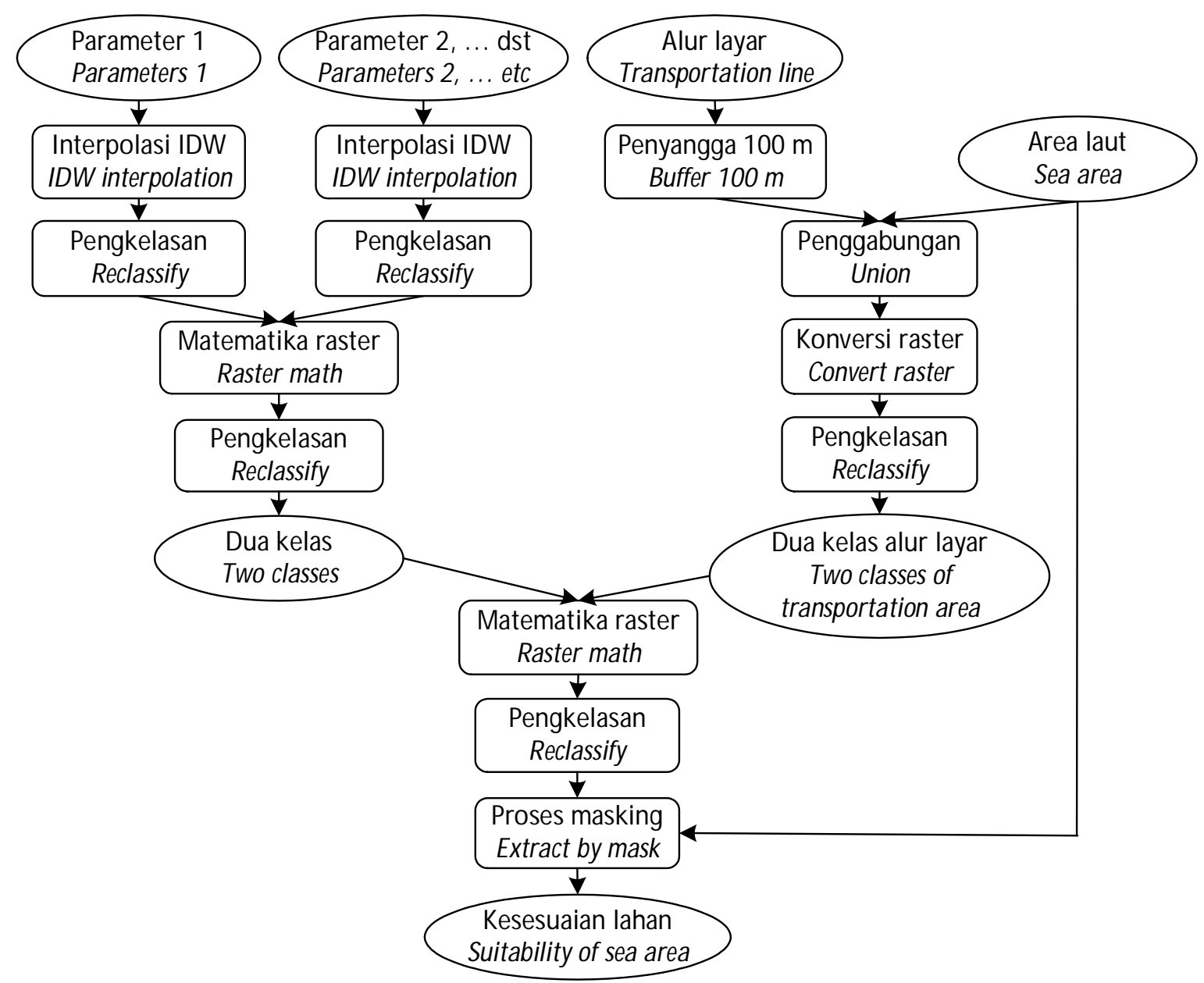

Gambar 2. Diagram alir pemrosesan data.

Figure 2. Research design for the site suitability data analysis.

(Tabel 1). Hasil yang diperoleh menunjukan bahwa aspek keterlindungan, $\mathrm{pH}$, suhu, salinitas, dasar perairan, DO, amonia, nitrat, fosfat masuk dalam kategori sesuai untuk budidaya rumput laut, sehingga parameter tersebut tidak diperhitungkan dalam analisis spasial. Parameter yang memiliki nilai minimum hingga maksimum yang bervariasi dari kriteria budidaya rumput laut diperhitungkan untuk analisis spasial sebanyak empat parameter. Parameter tersebut adalah batimetri, kecepatan arus, dan kecerahan perairan, serta ditambah jalur transportasi laut atau area pelayaran.

Bakosurtanal (2005) memberikan bobot yang tinggi pada parameter kedalaman dan kecerahan, namun tidak memperhitungkan arus dalam penilainya, sedangkan dalam SNI 7579.2:2010 (BSN, 2010), Ariyati et al. (2007), Akbar (2014), Mustafa et al. (2017), parameter arus harus diperhitungkan dalam penilaian.

Dasar perairan Mulut Seribu berupa karang berpasir, serta jauh dari muara sungai, sehingga perairan ini sangat baik untuk pengembangan budidaya rumput laut.

Parameter TSS di beberapa penelitian tidak diperhitungkan dalam penentuan lokasi kesesuaian budidaya rumput laut (Hasnawi et al., 2013; PongMasak et al., 2010; Radiarta et al., 2012; Ariyati et al., 2007). Penelitian lain memperhitungkan TSS (Akbar, 2014), yang mengacu pada Keputusan Menteri 02/ MenKLH///1988 (KLH, 1988). Nilai TSS yang diharapkan adalah di bawah $25 \mathrm{mg} / \mathrm{L}$ dan masih diperbolehkan pada nilai di bawah $80 \mathrm{mg} / \mathrm{L}$. Dalam penelitian ini, nilai TSS masih di bawah $80 \mathrm{mg} / \mathrm{L}$, sehingga masih sesuai untuk budidaya rumput laut.

Tingginya TSS dapat memengaruhi kehidupan organisme yaitu terhambatnya penetrasi cahaya ke kolom air yang menyebabkan terganggunya proses fotosintesis sehingga dapat mengganggu pertumbuhan rumput laut. Nilai TSS di atas $25 \mathrm{mg} / \mathrm{L} \mathrm{di}$ lokasi penelitian perlu dijadikan pertimbangkan lebih lanjut, seperti dengan menunda penanaman pada 
Tabel 2. Kisaran nilai parameter dan standar deviasi kualitas perairan pada kawasan perairan Teluk Mulut Seribu

Table 2. The value ranges and standard deviation of water quality parameters in the Mulut Seribu Bay

\begin{tabular}{|c|c|c|c|c|c|c|}
\hline $\begin{array}{l}\text { Parameter } \\
\text { Parameters }\end{array}$ & $\begin{array}{l}\text { Satuan } \\
\text { Uunits }\end{array}$ & $\begin{array}{l}\text { Minimal } \\
\text { Minimal }\end{array}$ & $\begin{array}{l}\text { Rata-rata } \\
\text { Average }\end{array}$ & $\begin{array}{l}\text { Maksimal } \\
\text { Maximal }\end{array}$ & Stdev & $\begin{array}{l}\text { Keterangan } \\
\text { Information }\end{array}$ \\
\hline $\begin{array}{l}\text { Keterlindungan } \\
\text { Sheltered }\end{array}$ & $\mathrm{m}$ & 3 & 12.3 & 28 & 3.13 & $\begin{array}{l}\text { Sesuai } \\
\text { Suitable }\end{array}$ \\
\hline $\begin{array}{l}\text { Batimetri } \\
\text { Bathymetry }(\mathrm{m})\end{array}$ & & & & & & $\begin{array}{l}\text { Diinterpolasi } \\
\text { Interpolated }\end{array}$ \\
\hline $\begin{array}{l}\text { Kecepatan arus } \\
\text { Current speed }\end{array}$ & $\mathrm{cm} / \mathrm{dt}$ & 1.5 & 13.5 & 39.6 & 0.099 & $\begin{array}{l}\text { Diinterpolasi } \\
\text { Interpolated }\end{array}$ \\
\hline $\begin{array}{l}\text { Kecerahan perairan } \\
\text { Transparency }\end{array}$ & $\mathrm{m}$ & 2,000 & 3,782 & 6,500 & 1,055 & $\begin{array}{l}\text { Diinterpolasi } \\
\text { Interpolated }\end{array}$ \\
\hline pH & & 8,140 & 8,223 & 8,360 & 0.051 & $\begin{array}{l}\text { Sesuai } \\
\text { Suitable }\end{array}$ \\
\hline $\begin{array}{l}\text { Suhu } \\
\text { Temperature }\end{array}$ & ${ }^{\circ} \mathrm{C}$ & 28,980 & 29,584 & 30,190 & 0.296 & $\begin{array}{l}\text { Sesuai } \\
\text { Suitable }\end{array}$ \\
\hline $\begin{array}{l}\text { Salinitas } \\
\text { Salinity }\end{array}$ & ppt & 30,020 & 30,756 & 31,070 & 0.252 & $\begin{array}{l}\text { Sesuai } \\
\text { Suitable }\end{array}$ \\
\hline $\begin{array}{l}\text { Dasar perairan } \\
\text { Bottom bed }\end{array}$ & & & & & & $\begin{array}{l}\text { Sesuai } \\
\text { Suitable }\end{array}$ \\
\hline $\begin{array}{l}\text { Oksigen terlarut } \\
\text { Dissolved oxygen (DO) }\end{array}$ & $\mathrm{mg} / \mathrm{L}$ & 5,060 & 6,051 & 7,660 & 0.566 & $\begin{array}{l}\text { Sesuai } \\
\text { Suitable }\end{array}$ \\
\hline $\begin{array}{l}\text { Amonia } \\
\text { Ammonia (Nh3-N) }\end{array}$ & $\mathrm{mg} / \mathrm{L}$ & 0.101 & 0.136 & 0.184 & 0.025 & $\begin{array}{l}\text { Sesuai } \\
\text { Suitable }\end{array}$ \\
\hline $\begin{array}{l}\text { Nitrat } \\
\text { Nitrate }\end{array}$ & $\mathrm{mg} / \mathrm{L}$ & 0.124 & 0.172 & 0.313 & 0.048 & $\begin{array}{l}\text { Sesuai } \\
\text { Suitable }\end{array}$ \\
\hline $\begin{array}{l}\text { Fosfat } \\
\text { Phosphate }\end{array}$ & $\mathrm{mg} / \mathrm{L}$ & 0.022 & 0.036 & 0.049 & 0.008 & $\begin{array}{l}\text { Sesuai } \\
\text { Suitable }\end{array}$ \\
\hline $\begin{array}{l}\text { Total padatan tersuspensi } \\
\text { Total suspended solid (TSS) }\end{array}$ & $\mathrm{mg} / \mathrm{L}$ & 40,000 & 49,067 & 55,000 & 4,203 & $\begin{array}{l}\text { Sesuai } \\
\text { Suitable }\end{array}$ \\
\hline $\begin{array}{l}\text { Alur pelayaran } \\
\text { Sea transportation line }\end{array}$ & & & & & & $\begin{array}{l}\text { Diproses } \\
\text { Proceed }\end{array}$ \\
\hline
\end{tabular}

bulan-bulan dengan curah hujan tinggi atau dengan tetap menanam namun bukan dengan metode lepas dasar. Sebagian besar metode yang digunakan di Pulau Rote adalah metode longline atau tali panjang yang dibentangkan dan ditenggelamkan beberapa sentimeter di bawah permukaan laut, dengan metode ini rumput laut masih dapat bertahan dengan baik, karena masih bisa mendapatkan cahaya matahari. Pengalaman dari petani rumput laut di Nunukan, menyebutkan bahwa dalam kondisi perairan yang keruh (kemungkinan TSS tinggi) dapat diatasi dengan membenamkan tali sekitar $25 \mathrm{~cm}$ di bawah permukaan laut, tidak boleh lebih dari itu. Pemantauan di lapangan budidaya rumput laut bisa tetap dilaksanakan pada lokasi penelitian, walaupun dengan kondisi TSS yang cukup tinggi.

Dasar perairan Mulut Seribu berupa karang berpasir, serta jauh dari muara sungai, sehingga perairan ini sangat baik untuk pengembangan budidaya rumput laut. Faktor kedalaman perairan merupakan salah satu parameter kunci dalam pemilihan lokasi kegiatan budidaya perairan, dan pengaruhnya spesifik pada jenis komoditas yang dibudidayakan. Hasil pengukuran insitu dan analisis data kedalaman kawasan perairan Teluk Mulut Seribu diperoleh kedalaman ratarata $12,3 \mathrm{~m}$ dan maksimum sekitar $28 \mathrm{~m}$. Kedalaman yang diinginkan adalah antara nilai 2-15 $\mathrm{m}$. Hasil 
interpolasi dan pengkelasan menunjukkan area yang tidak sesuai berdasarkan kedalaman sebagian besar berada pada sekitar pertengahan teluk mendekati mulut teluk, areanya lebih kecil daripada kelas sesuai seperti yang ditunjukkan oleh Gambar 3.

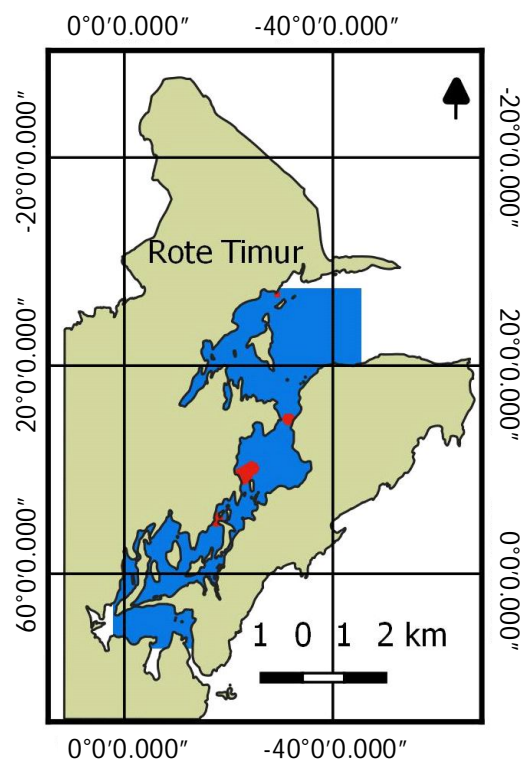

Legenda (Legend):

Kecepatan arus (Current speed)

- Tidak sesuai (Unsuitable)

Sesuai (Suitable)

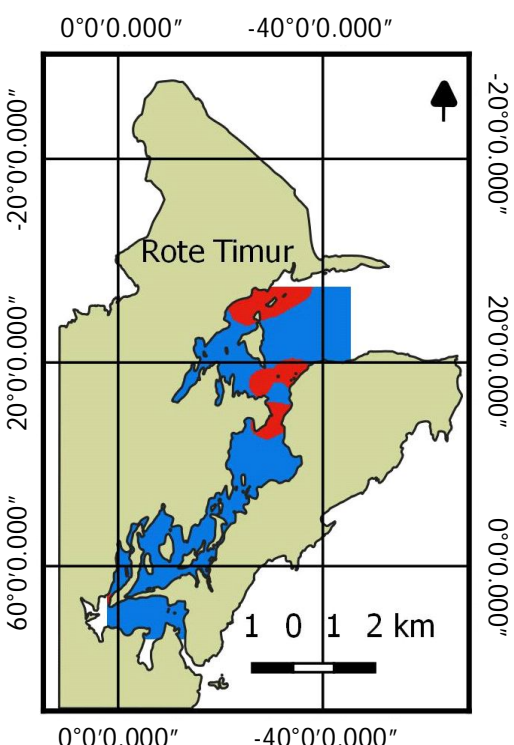

Legenda (Legend):

Kecerahan (Transparency)

Tidak sesuai (Unsuitable)

Sesuai (Suitable)
Kecepatan arus area penelitian nilainya berkisar antara 1,5-39,6 cm/dt, dengan rata-rata $13,5 \mathrm{~cm} / \mathrm{dt}$. Nilai kisaran yang diinginkan adalah $10-40 \mathrm{~cm} / \mathrm{dt}$. Hasil interpolasi dan klasifikasi menunjukan sebagian besar area memenuhi kriteria arus, hanya sebagian kecil yang tidak memenuhi kriteria (Gambar 3).

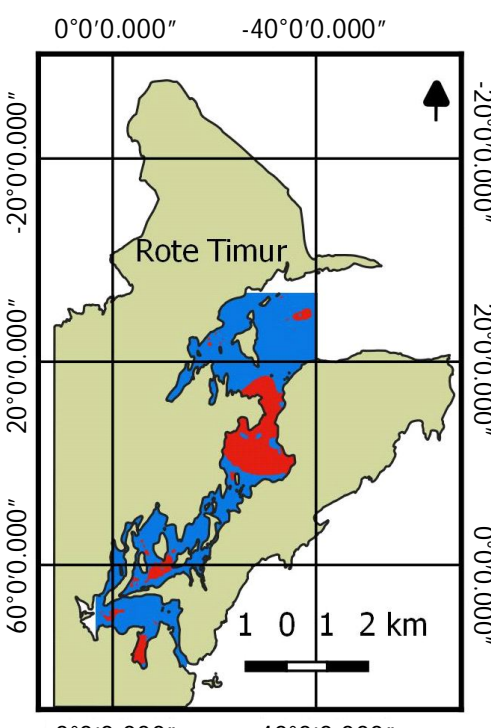

$0^{\circ} 0^{\prime} 0.000^{\prime \prime} \quad-40^{\circ} 0^{\prime} 0.000^{\prime \prime}$ Legenda (Legend):

Kedalaman (Depth)

Tidak sesuai (Unsuitable)

Sesuai (Suitable)

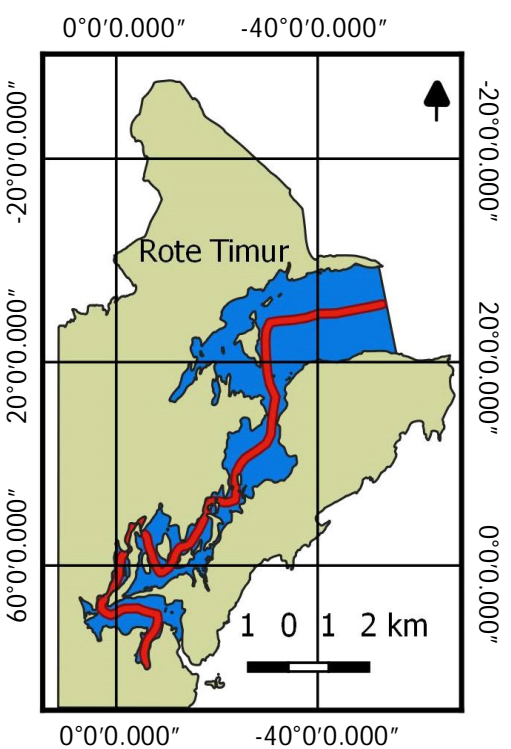

Legenda (Legend):

Alur pelayaran (Sea transportation

Tidak sesuai (Unsuitable)

Sesuai (Suitable)

Gambar 3. Hasil interpolasi dan klasifikasi berdasarkan kriteria kesesuaian lokasi.

Figure 3. The result of interpolation and classification based on the site suitability criteria. 
Kecerahan daerah penelitian nilainya berkisar antara 2-6 m, dengan rata-rata 3,7 m. Nilai yang diinginkan adalah di atas $3 \mathrm{~m}$. Hasil interpolasi dan klasifikasi berdasarkan kriteria menunjukkan sebagain besar area sesuai untuk budidaya rumput laut, area yang tidak sesuai berada di dekat mulut teluk dan agak ke tengah seperti yang ditunjukan oleh Gambar 3.

\section{Analisis Spasial Kesesuaian Lahan}

Hasil analisis kesesuaian lahan berdasarkan overlay secara raster dari empat parameter, serta faktor pembatas alur pelayaran (Gambar 3), diperoleh hasil dua kelas kesesuaian yaitu sesuai dan tidak sesuai. Luasan untuk area yang sesuai diperoleh hasil seluas 497,68 ha sedangkan area yang tidak sesuai seluas 381,5 ha, seperti yang ditunjukkan oleh Gambar 4.

jika diasumsikan produktivitas rumput laut basah 100 ton/ha, maka apabila lahan di Teluk Mulut Seribu dimanfaatkan seluruhnya dapat menghasilkan produksi sekitar 49.768 ton dalam sekali panen. Angka tersebut tentu saja angka yang cukup besar, namun tentu saja pemanfaatan lahan membutuhkan sumberdaya yang mengelolanya untuk dapat mencapai hasil tersebut. Dari sisi ketersediaan lahan, Teluk Mulut Seribu masih sangat potensial untuk dikembangkan.

\section{KESIMPULAN}

Berdasarkan hasil penelitian ini dapat disimpulkan bahwa perairan di Pulau Rote terutama perairan di Teluk Mulut Seribu merupakan perairan yang masih bersih dan dapat mendukung usaha budidaya rumput laut. Dari 13 parameter yang diperhitungkan dalam penelitian ini sembilan parameter menunjukkan nilai yang sesuai untuk budidaya rumput laut. Kemudian tiga parameter lainnya yaitu kecerahan, arus, dan batimetri memiliki julat nilai yang bervariasi, serta satu parameter pembatas yaitu alur laut. Berdasarkan analisis spasial dari keempat parameter tersebut dihasilkan 497,68 ha area yang sesuai untuk budidaya rumput laut yang belum dimanfaatkan seluruhnya. Sedangkan ada sekitar 381,5 ha area yang tidak sesuai, sehingga peluang untuk pengembangan budidaya rumput laut masih terbuka luas dari sisi ketersediaan lahan.

\section{UCAPAN TERIMA KASIH}

Penulis mengucapkan terima kasih dan penghargaan kepada Pusat Penelitian dan Pengembangan Perikanan, Badan Penelitian dan pengembangan Perikanan dan Kelautan, KKP melalui pembiayaan DIPA T.A. 2016. Ucapan terima kasih

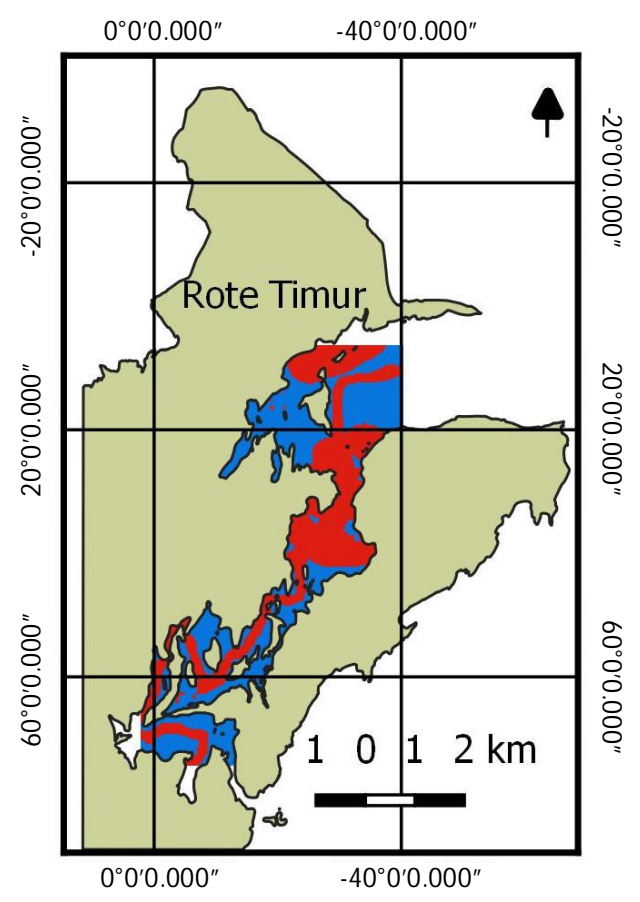

\section{Legenda (Legend): \\ Tidak sesuai (Unsuitable) \\ Sesuai (Suitable)}

Gambar 4. Peta kesesuaian lahan untuk budidaya rumput laut.

Figure 4. Site suitability for seaweed cultivation Mulut Seribu Bay, Rote Ndao. 
kepada Bapak Prof. Ketut Sugama, M. Sc., Ph.D. yang telah banyak memberikan dukungan, arahan, dan motivasi; tim survai yang tidak bisa disebutkan namanya satu per satu, serta kepada Bupati Kabupaten Rote-Ndao, Bapak Drs. Leonard Haning, M.M., beserta seluruh jajarannya, Bapak Kepala Desa, Sekretaris Desa, dan masyarakat Rote-Ndao yang telah membantu kelancaran penelitian ini.

\section{DAFTAR ACUAN}

Affan, J.M. (2012). Identifikasi lokasi untuk pengembangan budidaya keramba jaring apung (KJA) berdasarkan faktor lingkungan dan kualitas air di perairan pantai timur Bangka Tengah. Depik, 1(1), 78-85. ISSN 2089-7790.

Akbar, H. (2014). Analisis kesesuaian lokasi untuk budidaya rumput laut di Kabupaten Sumbawa Barat. Tesis. Sekolah Pascasarjana Institut Pertanian Bogor.

Ariyati, R.W., Sya'rani, L., \& Arini, E. (2007). Analisis kesesuaian perairan Pulau Karimunjawa dan Pulau Kemujan sebagai lahan budidaya rumput laut menggunakan sistem informasi geografi. Jurnal Pasir Laut, 3(1), 27-45.

Badan Koordinasi Survei dan Pemetaan Nasional [Bakosurtanal]. (2005). Prosedur dan spesifikasi teknis analisis kesesuaian budidaya rumput laut. Pusat Survei Sumberdaya Alam Laut Bakosurtanal Cibinong, Bogor, hlm. 1-36.

Badan Standarisasi Nasional [BSN]. (2010). Produksi rumput laut kotoni (Euchema cottonii) Bagian 2: Metode longline. SNI 7579.2:2010, $13 \mathrm{hlm}$.

Badan Standarisasi Nasional [BSN]. (2015). Kualitas air laut Bagian 8: Metode pengambilan contoh uji air laut. SNI 6964.8:2015, $26 \mathrm{hlm}$.

Direktorat Jenderal Perikanan Budidaya [DJPB]. (2015). Produksi komoditas utama Provinsi Nusa Tenggara Timur.

Hasnawi, Makmur, Paena, M., \& Mustafa, A. (2013). Analisis kesesuaian lahan budidaya rumput laut (Kappaphycus alvarezii) di Kabupaten Parigi Moutong Provinsi Sulawesi Tengah. Jurnal Riset Akuakultur, 8(3), 493-505.

Juanich, G.L. (1988). Manual on seaweed farming (Eucheuma spp.). ASEAN/UNDP/FAO Regional SmallScale Coastal Fisheries Development Project Manila, Philippines. ASEAN/SF/88/Manual No. 2.

Kementerian Lingkungan Hidup [KLH]. (1988). Keputusan Kementerian Lingkungan Hidup No. 02 tahun 1988 tentang Baku Mutu Lingkungan untuk Biota Laut (Budidaya perikanan).

Kementerian Lingkungan Hidup [KLH]. (2004). Keputusan Menteri Negara Kependudukan dan
Lingkungan Hidup No. 51 tahun 2004, tanggal 8 April 2004 tentang baku mutu air laut. $11 \mathrm{hlm}$.

Kementerian Kelautan dan Perikanan [KKP]. (2016). KKP Anggarkan Rp305 Miliar Bangun Kawasan Perikanan Terpadu. http://news.kkp.go.id/ index.php/kkp-anggarkan-rp-305-miliar-bangunkawasan-perikanan-terpadu/. (diakses pada 21 Juli 2016).

Mudeng, J.D., Ngangi, E.L.A., \& Rompas, R.J. (2015). Identifikasi parameter kualitasair untuk kepentingan marikultur di Kabupaten Kepulauan Sangihe Provinsi Sulawesi Utara. Jurnal Budidaya Perairan, 3(1), 141-148.

Mustafa, A., Tarunamulia, Hasnawi, \& Radiarta, I N. (2017). Karakteristik, kesesuaian, dan daya dukung perairan untuk budidaya rumput laut di Kabupaten Kepulauan Sangihe, Sulawesi Utara. Jurnal Riset Akuakultur, 12(2), 187-196.

Pemerintah Kabupaten Rote Ndao. (2009). Peraturan Daerah Nomor 19 Tahun 2009 Tentang Rencana Pembangunan Jangka Panjang Daerah (RPJPD) Kabupaten Rote Ndao Tahun 2005-2025.

Pemerintah Kabupaten Rote Ndao. (2014). Peraturan Daerah Kabupaten Rote Ndao Nomor 4 Tahun 2014 tentang Rencana Pembangunan Jangka Menengah Daerah (RPJMD) Kabupaten Rote Ndao 2014-2019, $14 \mathrm{hlm}$.

Pemerintah Kabupaten Rote Ndao. (2015). Laporan akhir kajian analisis hidrooseanografi di perairan Kabupaten Rote Ndao tahun 2015, $60 \mathrm{hlm}$.

Pong-Masak, P.R., Asaad, A.I.J., Hasnawi, Pirzan, A.M., \& Lanuru, M. (2010). Analisis kesesuaian Iahan untuk pengembangan budidaya rumput laut di Gusung Batua, Pulau Badi Kabupaten Pangkep, Sulawesi Selatan. Jurnal Riset Akuakultur, 5(2), 299-316.

Pramono, G.H. (2008). Akurasi metode IDW dan kriging untuk interpolasi sebaran sedimen tersuspensi. Forum Geografi, 22(1), Juli, 22(1), 97-110.

Radiarta, I N., Saputra, A., Haryadi, J., Johan, 0., \& Prihadi, T.H. (2006). Pemilihan lokasi budidaya ikan dalam keramba jaring apung menggunakan analisis multi kriteria dan sistem informasi geografis di Teluk Kapontori, Sulawesi Tenggara. Jurnal Riset Akuakultur, 1(3), 303-318.

Radiarta, I N., Saputra, A., \& Albasri, H. (2012). Pemetaan kelayakan lahan budidaya rumput laut (Kappaphycus alvarezii) di Kabupaten Bintan Provinsi Kepulauan Riau dengan pendekatan sistem informasi geografis dan penginderaan jauh. Jurnal Riset Akuakultur, 7(1), 145-157. 